\title{
FAST AND HIGHLY SENSITIVE LASER SCANNER FOR RECORDING PHOTON- UPCONVERSION LUMINESCENCE FROM PLANAR SURFACES
}

\author{
Antonín HLAVÁČEK, Jana KŘIVÁNKOVÁ, František FORET \\ Institute of Analytical Chemistry of the Czech Academy of Sciences, Brno, Czech Republic, EU, \\ hlavacek@iach.cz
}

https://doi.org/10.37904/nanocon.2019.8563

\begin{abstract}
Photon-upconversion nanoparticles (UCNPs) are lanthanide-doped nanocrystals that can be excited by nearinfrared light and emit photon-upconversion luminescence of shorter wavelengths. Advantages of UCNPs include near-infrared excitation, multiple and narrow emission bands, negligible autofluorescence and high stability, which make UCNPs ideal luminescence label for use in biological and chemical assays. These assays - e.g. upconversion-linked immunosorbent assay, western blot, lateral flow assay, gel electrophoresis, thin layer chromatography - commonly require the scanning of a planar surface with a high spatial resolution and an excellent sensitivity. The availability of commercial equipment is recently limited because of the novelty of the photon-upconversion phenomenon. Therefore, we report on the construction of photon-upconversion laser scanner. The scanner consists of a laser scanning head, which is attached to a xy-moving stage. The scanning head itself is constructed as an epiluminescence detector with excitation wavelength of $976 \mathrm{~nm}$. A CCD array spectroscope is connected to the laser head and serves as a sensitive detector of photon-upconversion luminescence. The scanner possesses a spatial resolution of $200 \mu \mathrm{m}$, the scanning rate is up to 57 points per second and the sensitivity reaches down to single photon-upconversion nanoparticle.
\end{abstract}

Keywords: Photon-upconversion, nanoparticle, laser scanner, hyperspectral imaging

\section{INTRODUCTION}

Multiplexed assays are suitable for parallel analyte detection. Even in complex mixtures, multiplexed detection reduces the consumption of sample, reagents, and other resources [1-5]. The applications of multiplexed assays range from single-cell [6] and single-molecule assays [7], medical diagnostics [1], detecting biomolecule interactions [8], environmental monitoring [9], pathogen detection [10], multiparameter chemical and biological assays [11] and screening of chemical libraries [12].

Photon-upconversion nanoparticles (UCNPs) are luminescence labels, which are widely considered as a vital alternative to fluorescence reporter in multiplexed assays [13-15]. UCNPs are lanthanide-doped nanocrystals that can be excited by near-infrared light and emit photon-upconversion luminescence of shorter wavelengths [16-18]. Advantages of photon-upconversion nanoparticles include near-infrared excitation, multiple and narrow emission bands, negligible autofluorescence and high stability. The assays with UCNPs - e.g. upconversion-linked immunosorbent assay, western blot, lateral flow assay, gel electrophoresis, thin layer chromatography - commonly require the scanning of planar surfaces with a high spatial resolution and an excellent sensitivity. Currently reported equipment (photon upconversion scanners) only allows for reading the sum of intensities in a single spectral range [19].

Here, we address this limitation and introduce a hyperspectral photon-upconversion laser scanner. The laboratory-made scanner consists of an epiluminescence laser scanning head, which is attached to a xymoving stage. A CCD array spectroscope is connected to the laser head and serves as a sensitive detector of photon-upconversion luminescence. We provide the comparison of scanning for three types of nanoparticles containing either $\mathrm{Ho}^{3+}, \mathrm{Er}^{3+}$ or $\mathrm{Tm}^{3+}$ as activator ions. We also show the capability of scanner to record emission spectrum from a single UCNP. 


\section{MATERIAL AND METHODS}

\subsection{Scanner construction and control}

The scanner was composed of two modular parts. (A) The first part was an epiluminescence detector (Figure 1), which consisted of microscope objective (magnification 25×, numerical aperture 0.40 or magnification 100×, numerical aperture 1.25, Olympus), dichroic mirror ( $900 \mathrm{~nm}$ short pass, ThorLabs), optical filters (875 nm short pass and $925 \mathrm{~nm}$ long pass, Edmund Optics) and a CCD array spectrometer (QE65000, Ocean Optics). In each scanned point, the emission spectrum of photon-upconversion was recorded in a range from 430 to $875 \mathrm{~nm}$. The spectroscope was optionally replaced with an sCMOS camera for single nanoparticle imaging (Zyla 5.5, Andor). Photon-upconversion luminescence was excited by $976 \mathrm{~nm} 1 \mathrm{~W}$ laser diode (Laserland). The dichroic mirror reflected the excitation laser beam on a scanned object through a microscope objective. The same microscope objective also collected emitted luminescence into the spectroscope. (B) The second part of the scanner was a xy-moving stage, which holds the epiluminescence detector and allowed its moving in two dimensions with step of $200 \mu \mathrm{m}$. The moving stage was controlled by Arduino Nano board. A universal serial bus was used for communication with personal computer with the Windows 10 operating system. A graphical Java application was used for controlling the scanner xy-moving stage and recording data from the spectroscope. The output data were saved in the form of text files.

\section{Spectroscope}

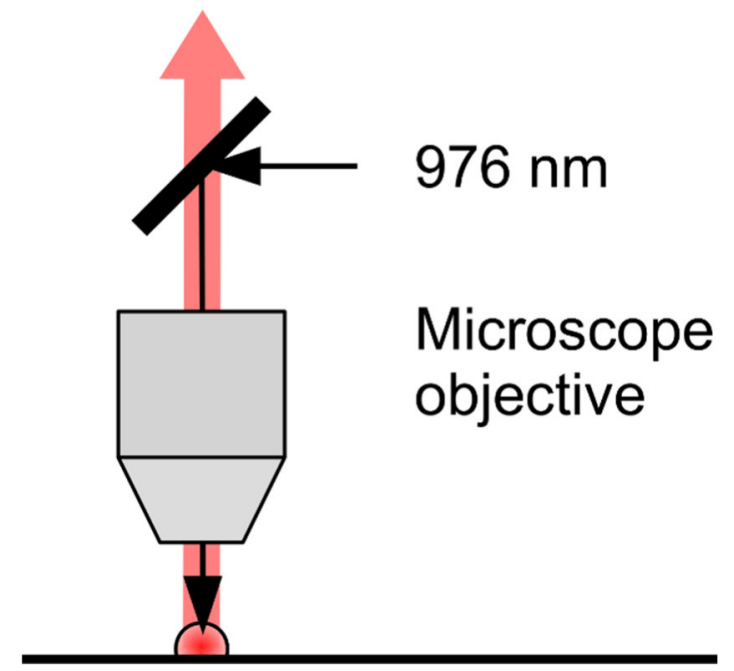

Figure 1 The scheme of epiluminescence detector. The dichroic mirror reflects the excitation laser beam $(976 \mathrm{~nm})$ on a scanned object through a microscope objective (black line). The same microscope objective also collects emitted luminescence from UCNPs into the spectroscope (red line).

\subsection{Nanoparticle synthesis and characterization}

According to previous reports, the nanoparticles were prepared by thermal decomposition of oleates at high temperature $\left(\sim 300{ }^{\circ} \mathrm{C}\right)$ [20]. After surface coating by carboxylated silica, the nanoparticles created stable dispersions in water $[20,21]$. The mass concentration of UCNPs in water was measured by a gravimetric method: The volume of $200 \mu \mathrm{L}$ of UCNPs dispersion was loaded into a glass vial. The vial was placed first on a heater to evaporate water and then for 3 hours in an oven at $450^{\circ} \mathrm{C}$ and the mass of remaining UCNPs was measured. To estimate the hydrodynamic diameters of UCNPs, dynamic light scattering (DLS) of UCNP water or cyclohexane dispersions was measured in a glass cuvette with a $10 \mathrm{~mm}$ optical path. The volume of dispersion was $1000 \mu \mathrm{L}$ and the mass concentration of UCNPs was $0.5 \mathrm{mg} \mathrm{mL}^{-1}$. 


\section{RESULTS AND DISCUSSION}

\subsection{Photon-upconversion nanoparticles}

Four types of UCNPs were prepared (Table 1). Three types of photon-upconversion nanoparticles (UCNP1-3) were prepared for hyperspectral scanning on a microtiter plate. The sizes of the luminescent core of these nanoparticles were approximately $30 \mathrm{~nm}$. The chemical composition of these UCNPs differed in the type of activator ion (either $\mathrm{Tm}^{3+}, \mathrm{Er}^{3+}$ or $\mathrm{Ho}^{3+}$ ). The fourth nanoparticle type (UCNP4) with $127 \mathrm{~nm}$ luminescent core was used for the measurement of single nanoparticle emission spectrum. The emission spectra of UCNP1-4 (Figure 2) were recorded from water dispersions (100 $\mu \mathrm{L}$ per well) on a microtiter plate by photonupconversion laser scanner. The emission spectra revealed narrow emission peaks, which are typical for $\mathrm{Ho}^{3+}$, $\mathrm{Er}^{3+}$ and $\mathrm{Tm}^{3+}$ doped UCNPs as it is shown in Figure 2.

Table 1 The list of prepared photon-upconversion nanoparticles

\begin{tabular}{|c|c|c|c|}
\hline $\begin{array}{c}\text { Nanoparticle } \\
\text { type }\end{array}$ & Nanoparticle composition & $\begin{array}{c}\text { Hydrodynamic diameter } \\
\text { without silica shell in } \\
\text { cyclohexane (nm) }\end{array}$ & $\begin{array}{c}\text { Hydrodynamic diameter with } \\
\text { silica shell in water (nm) }\end{array}$ \\
\hline UCNP1 & $\mathrm{NaY}_{0.80} \mathrm{Yb}_{0.18} \mathrm{Ho}_{0.02} \mathrm{~F}_{4}$ & 30.5 & 48.4 \\
\hline UCNP2 & $\mathrm{NaY}_{0.80} \mathrm{Yb}_{0.18} \mathrm{Er}_{0.02} \mathrm{~F}_{4}$ & 31.2 & 83.5 \\
\hline UCNP3 & $\mathrm{NaY}_{0.80} \mathrm{Yb}_{0.18} \mathrm{Tm}_{0.02} \mathrm{~F}_{4}$ & 28.4 & 39.4 \\
\hline UCNP4 & $\mathrm{NaY}_{0.80} \mathrm{Yb}_{0.18} \mathrm{Er}_{0.02} \mathrm{~F}_{4}$ & 127 & 158 \\
\hline
\end{tabular}

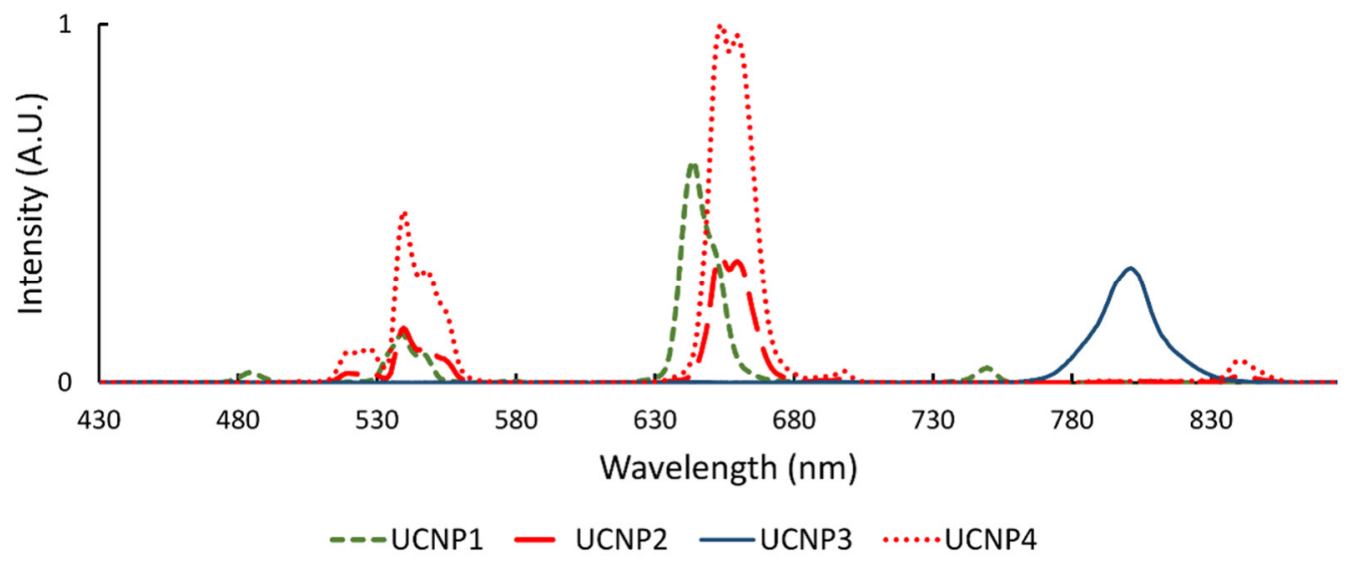

Figure 2 Emission spectra of UCNPs. Emission spectra of UCNP water dispersions measured from the microtiter plate by a photon-upconversion laser scanner $(100 \mu \mathrm{L}$ per well, integration time $1 \mathrm{~s})$. The concentrations of UCNPs were $10 \mathrm{mg} \mathrm{mL}^{-1}, 0.25 \mathrm{mg} \mathrm{mL}^{-1}, 0.13 \mathrm{mg} \mathrm{mL}^{-1}$ and $0.25 \mathrm{mg} \mathrm{mL}^{-1}$ for UCNP1-4, respectively.

\subsection{Scanning of nanoparticle dispersions on a microtiter plate}

Dispersions containing either UCNP1, UCNP2 or UCNP3 were prepared and dispensed into 96-well clear microtiter plate $(100 \mu \mathrm{L}$ per well). Utilizing a microscope objective with magnification $25 \times$ and numerical aperture 0.4 , the plate was scanned with a spatial resolution of $200 \mu \mathrm{m}$. The integration time of $10 \mathrm{~ms}$ was used for recording the emission spectrum from each point with a reading speed of 57 points per second. To show the advantages of hyperspectral scanning, we recorded the sum of emission intensities for three different spectral ranges, i.e., detection channels. Those channels were subsequently used for constructing colored image (red channel: emission 621-707 nm, green channel: emission 512-572 nm, blue channel: emission 759- 
$860 \mathrm{~nm}$, Figure 3). From Figure 3, it is clear that hyperspectral scanning allows projecting different types of nanoparticles as different colors, which can be advantageously used for signal multiplexing.

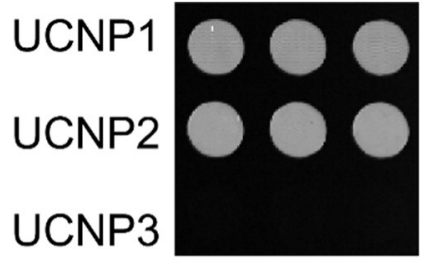

Red

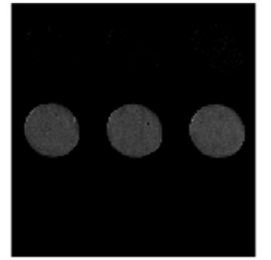

Green

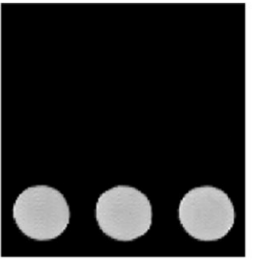

Blue Red/Green/Blue

Figure 3 Hyperspectral scanning of UCNP dispersions on a microtiter plate. Dispersions of UCNP1-3 were loaded on 96 well microtiter plate $\left(100 \mu \mathrm{L}\right.$ per well, $10 \mathrm{mg} \mathrm{mL}^{-1}, 0.25 \mathrm{mg} \mathrm{mL}^{-1}$ and $0.13 \mathrm{mg} \mathrm{mL}^{-1}$ for UCNP1-3, respectively) and scanned with a resolution of $200 \mu \mathrm{m}$ with $10 \mathrm{~ms}$ integration time per scanned point. Three channels are projected for three different spectral ranges (red channel: emission 621-707 nm, green channel: emission 512-572 nm, blue channel: emission 759-860 nm). These channels were projected as a colored image (red/green/blue).

\subsection{Recording the emission spectrum of single photon-upconversion nanoparticle}

We further tested whether the scanner is sensitive enough to record the emission of single nanoparticle on a planar surface, which can be important for the construction of photon-upconversion nanosensors. To record the emission spectrum of single nanoparticle, the glycerol immersion objective was used for focusing the excitation laser and collecting the emitted luminescence. The nanoparticles (UCNP4) were adsorbed on microscopic cover glass (150 $\mu \mathrm{m}$ thickness) and imaged by sCMOS camera (integration time $30 \mathrm{~ms}$ ) as it was described previously. The emission spectrum was recorded (integration time $10 \mathrm{~s}$, Figure 4) when the area of the substrate containing only single nanoparticle in the field of view was selected.

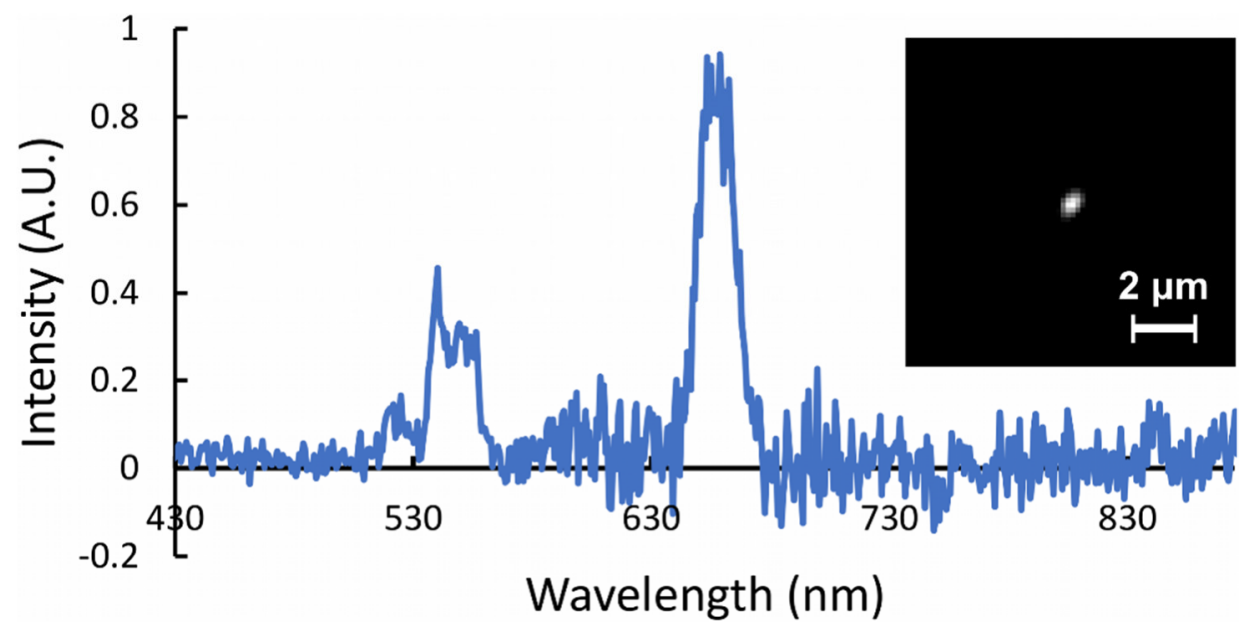

Figure 4 Emission spectrum of single UCNP. The emission spectrum of a single UCNP4 was recorded.

The inset shows the image of single UCNP4 from sCMOS camera.

\section{CONCLUSION}

We constructed a hyperspectral epiluminescence laser scanner, which allows recording an emission spectrum in each point of the scanned image. The scanner provides an advantage over laser scanners, which are able to record only the sum of intensities within single range of wavelengths. In this study we have shown that multiple detection channels can be extracted from recorded data and those channels can be used for 
constructing colored images; different colors are projected for different types of photon-upconversion nanoparticles. We suppose that this multichannel sensing capability can be useful for analytical signal multiplexing and the development of multiplexed assays. We further showed that the scanner detector is sensitive enough even for recording the emission spectrum from single photon-upconversion nanoparticle, which can be useful for biosensor developing on the bases of single photon-upconversion nanoparticles.

\section{ACKNOWLEDGEMENTS}

\section{We acknowledge funding from the Czech Science Foundation (18-03367Y) and Institutional support RVO 68081715 of Institute of Analytical Chemistry, Czech Academy of Sciences in Brno, Czech Republic.}

\section{REFERENCES}

[1] YANG, M., LIU, Y. and JIANG, X. Barcoded point-of-care bioassays. Chemical Society Reviews. 2019. vol. 48, no. 3, pp. 850-884.

[2] LIN, G., BAKER, M.A.B., HONG, M. and JIN, D. The Quest for Optical Multiplexing in Bio-discoveries. Chem. 2018. vol. 4, no. 5, pp. 997-1021.

[3] XU, Y., WANG, H., CHEN, B., LIU, H. and ZHAO, Y. Emerging barcode particles for multiplex bioassays. Science China Materials. 2019. vol. 62, no. 3, pp. 289-324.

[4] LENG, Y., SUN, K., CHEN, X. and LI, W. Suspension arrays based on nanoparticle-encoded microspheres for high-throughput multiplexed detection. Chemical Society Reviews. 2015. vol. 44, no. 15, pp. 5552-5595.

[5] FANG, X., ZHENG, Y., DUAN, Y., LIU, Y. and ZHONG, W. Recent Advances in Design of Fluorescence-Based Assays for High-Throughput Screening. Analytical Chemistry. 2019. vol. 91, no. 1, pp. 482-504.

[6] KLEIN, A.M., MAZUTIS, L., AKARTUNA, I., TALLAPRAGADA, N., VERES, A., LI, V., PESHKIN, L., WEITZ, D.A. and KIRSCHNER, M.W. Droplet barcoding for single-cell transcriptomics applied to embryonic stem cells. Cell. 2015. vol. 161, no. 5, pp. 1187-1201.

[7] RISSIN, D.M., KAN, C.W., SONG, L., RIVNAK, A.J., FISHBURN, M.W., SHAO, Q., PIECH, T., FERRELL, E.P., MEYER, R.E., CAMPBELL, T.G., FOURNIER, D.R. and DUFFY, D.C. Multiplexed single molecule immunoassays. Lab on a Chip. 2013. vol. 13, no. 15, pp. 2902-2911.

[8] YAN, M., ZHU, Y., LIU, X., LASANAJAK, Y., XIONG, J., LU, J., LIN, X., ASHLINE, D., REINHOLD, V., SMITH, D.F. and SONG, X. Next-Generation Glycan Microarray Enabled by DNA-Coded Glycan Library and NextGeneration Sequencing Technology. Analytical Chemistry. 2019. vol. 91, no. 14, pp. 9221-9228.

[9] ZHANG, L., GUAN, L., LU, Z., LI, M., WU, J., CAO, R. and TIAN, J. Barrier-free patterned paper sensors for multiplexed heavy metal detection. Talanta. 2019. vol. 196, pp. 408-414.

[10] LIANG, Y., LIU, Q., ZHOU, Y., CHEN, S., YANG, L., ZHU, M. and WANG, Q. Counting and Recognizing Single Bacterial Cells by a Lanthanide-Encoding Inductively Coupled Plasma Mass Spectrometric Approach. Analytical Chemistry. 2019. vol. 91, no. 13, pp. 8341-8349.

[11] BACCOUCHE, A., OKUMURA, S., SIESKIND, R., HENRY, E., AUBERT-KATO, N., BREDECHE, N., BARTOLO, J.-F., TALY, V., RONDELEZ, Y., FUJII, T. and GENOT, A.J. Massively parallel and multiparameter titration of biochemical assays with droplet microfluidics. Nature Protocols. 2017. vol. 12, no. 9, pp. 1912-1932.

[12] CHEN, C.-H., MILLER, M.A., SARKAR, A., BESTE, M.T., ISAACSON, K.B., LAUFFENBURGER, D.A., GRIFFITH, L.G. and HAN, J. Multiplexed protease activity assay for low-volume clinical samples using dropletbased microfluidics and its application to endometriosis. Journal of the American Chemical Society. 2013. vol. 135, no. 5, pp. 1645-1648.

[13] GORRIS, H.H. and WOLFBEIS, O.S. Photon-upconverting nanoparticles for optical encoding and multiplexing of cells, biomolecules, and microspheres. Angewandte Chemie - International Edition. 2013. vol. 52, no. 13, pp. 3584-3600.

[14] GORRIS, H.H., ALI, R., SALEH, S.M. and WOLFBEIS, O.S. Tuning the dual emission of photon-upconverting nanoparticles for ratiometric multiplexed encoding. Advanced Materials. 2011. vol. 23, no. 14, pp. 1652-1655. 
[15] HLAVÁČEK, A., KŘIVÁNKOVÁ, J., PŘIKRYL, J. and FORET, F. Photon-Upconversion Barcoding with Multiple Barcode Channels: Application for Droplet Microfluidics. Analytical Chemistry. 2019. Article ASAP. https://doi.org/10.1021/acs.analchem.9b03117.

[16] ZHOU, J., LIU, Q., FENG, W., SUN, Y. and LI, F. Upconversion luminescent materials: Advances and applications. Chemical Reviews. 2015. vol. 115, no. 1, pp. 395-465.

[17] ZHOU, L., FAN, Y., WANG, R., LI, X., FAN, L. and ZHANG, F. High-Capacity Upconversion Wavelength and Lifetime Binary Encoding for Multiplexed Biodetection. Angewandte Chemie - International Edition. 2018. vol. 57, no. 39 , pp. $12824-12829$.

[18] HUANG, K., IDRIS, N.M. and ZHANG, Y. Engineering of Lanthanide-Doped Upconversion Nanoparticles for Optical Encoding. Small. 2016. vol. 12, no. 7, pp. 836-852.

[19] SEDLMEIER, A., HLAVÁČEK, A., BIRNER, L., MICKERT, M.J., MUHR, V., HIRSCH, T., CORSTJENS, P.L.A.M., TANKE, H.J., SOUKKA, T. and GORRIS, H.H. Highly Sensitive Laser Scanning of Photon-Upconverting Nanoparticles on a Macroscopic Scale. Analytical Chemistry. 2016. vol. 88, no. 3, pp. 1835-1841.

[20] HLAVÁČEK, A., MICKERT, M.J., SOUKKA, T., LAHTINEN, S., TALLGREN, T., PIZÚROVÁ, N., KRÓL, A. and GORRIS, H.H. Large-Scale Purification of Photon-Upconversion Nanoparticles by Gel Electrophoresis for Analogue and Digital Bioassays. Analytical Chemistry. 2019. vol. 91, no. 2, pp. 1241-1246.

[21] HLAVÁČEK, A., SEDLMEIER, A., SKLÁDAL, P. and GORRIS, H.H. Electrophoretic characterization and purification of silica-coated photon-upconverting nanoparticles and their bioconjugates. ACS Applied Materials and Interfaces. 2014. vol. 6, no. 9, pp. 6930-6935. 